\title{
Comparison of Weight Gain, Milk Production, and Milk Composition of Iranian Mamasani Goat and its Cross with Saanen
}

\author{
Seyed Mahdi Hosseini ${ }^{1}$, Li Guo Yang ${ }^{1}$, Sayed Haidar Abbas Raza ${ }^{{ }_{2}}$, Rajwali Khan ${ }^{2}$, Majid Kalantar ${ }^{3}$, Sha- \\ hid Faraz Syed ${ }^{5}$, Mohib Ullah Kakar ${ }^{4}$ and Robina Manzoor ${ }^{4}$
}

${ }^{1}$ Key Laboratory of Agricultural Animal Genetics, Breeding and Reproduction of the Ministry of Education, College of Animal Science and Technology, Huazhong Agricultural University, Wuhan, China ${ }^{2}$ College of Animal Science and Technology, Northwest A\&F University, Yangling, Shaanxi, China

${ }^{3}$ Animal Science Department, Agricultural Research Center of Qom, Qom, Iran

${ }^{4}$ Lasbela University of Agriculture, Water and Marine Sciences(LUAWMS), Uthal, Baluchistan

${ }^{5}$ Faculty of veterinary and Animal Sciences, Lasbella University of Agriculture, Water and Marine Sciences,Uthal, Baluchistan, Pakistan

${ }^{*}$ Corresponding author: Sayed Haidar Abbas Raza, College of Animal Science and Technology, Northwest A\&F University, Yangling, Shaanxi, China, E-mail: dr.haiderabbasraza@gmail.com

Citation: Seyed Mahdi Hosseini, Li Guo Yang, Sayed Haidar Abbas Raza, Rajwali Khan, Majid Kalantar, et al. (2017) Comparison of Weight Gain, Milk Production, and Milk Composition of Iranian Mamasani Goat and its Cross with Saanen. J Vet Sci Ani Husb 5(2): 203. doi: 10.15744/2348-9790.5.203

Received Date: February 24, 2017 Accepted Date: May 22, 2017 Published Date: May 24, 2017

\begin{abstract}
Crossbreeding can be a breeding strategy to facilitate genetic improvement in native goat production. For this purpose, the performance of weight gain, milk production and milk composition of native Mamasani goat with Mamasani goat $\times$ Saanen $\left(\mathrm{F}_{1}\right)$ as crossed goat breed during 2012 to 2014 years were compared. According to the results, effect of genetic groups on birth weight (BW) was not significant but Weaning weight $(\mathrm{WW})$ was significant $(\mathrm{P}<0.05)$. The average birth weight and weaning weight for native Mamasani and crossed $F_{1}$ goats were $2.85 \pm 0.23 ; 2.98 \pm 0.19$ and $9.52 \pm 0.28 ; 11.61 \pm 0.28$ respectively. Milk yield in crossed $\mathrm{F}_{1}$ goats differed from Mamasani goats significantly, however milk composition in term of milk fat and milk protein content decreased significantly ( $\mathrm{P}$ $<0.05$ ). The average daily milk records were $0.65 \pm 0.05 \mathrm{~kg}$ for Mamasani goats, and $1.31 \pm 0.12 \mathrm{~kg}$ for crossed $\mathrm{F}_{1}$ goats respectively. These findings indicated that crossbreeding of native goats with Saanen had positive effects on performance traits such as weight gain and milk yield but could not improve the milk composition traits including fat and protein content.
\end{abstract}

Keywords: Goat; Mamasani Saanen; Milk production; Milk composition

\section{Introduction}

The performance of native Iranian goats is said to be adequate in terms of meat and hair production, although poor with regard to milk yields, probably because of unfavorable conditions [1]. Cross-breeding with Saanen goats promises improvements in milk production and growth rates, but the rearing performance and meat production ability of the native goats needs further evaluation [2]. There is a great potential for development of milk production from goats and recently projects for this purpose have been established in Iran [3]. These research projects are mainly concerned with evaluating milk production from native and crossbred goats [1]. Crossbreeding has the benefit of heterosis, as an initial stage of transition in establishing a breed which means "grading up" for the development of a new breed. The use of established dairy breeds for upgrading low producing or nondescript breeds for milk production is particularly relevant in unfavorable environments [2,4,5]. Whether up-grading or the development of a new breed is the best policy will depend on the environment and level of management [4]. The option of crossbreeding to introduce suitable genetic material for milk production is a much more rapid method than that of attempting to improve yield of native goat breeds by selection [6,7]. Crossbreeding results in heterosis for milk production and weight gain as it is apparent when the average performance of crossbred progeny is superior to the average performance of the two parents [8,9]. Mamasani goat is a native goat in Iran located in central regions of Iran. This breed of goat was kept to produce of fluff and milk, hair [1]. In this regard we described in the present study the futures of native Mamasani goat and its crosses with Saanen breed and evaluate the present and potential milk production capacity and weight gain of the existing native and imported goats stock.

\section{Materials and Methods}

In this study all animals were fed hay, wheat straw and concentrate with 12\% protein. Number of 94 Mamasani goats and 37 Mamasani $\times$ Saanen $\left(\mathrm{F}_{1}\right)$ were selected at a local farm in south of Qom province. Weights of experimental animals were recorded 
and weight gain data were adjusted regards to birth date and birth type according to birth date and birth type using Least Square Means (LSM) calculating procedures included Birth Weight (BW) and Weaning Weight (WW) of related kids. Raw milk samples $(\mathrm{n}=140)$ were obtained hygienically during 5 month lactation period and stored at $5{ }^{\circ} \mathrm{C}$ before analysis. Milk composition included fat and protein were analyzed by Milk Scope Julli C2 auto-analyzer in a laboratory of animal hospital in Qom city. Data were analyzed statistically using T-student procedure. P-values less than 0.05 were statistically significant. Estrus Synchronization and artificial insemination technology were used for Mamasani native goats and Saanen $\times$ Mamasani goats $\left(\mathrm{F}_{1}\right)$.

\section{Results and Discussion}

Birth body weights were similar between Mamasani and crossed $\mathrm{F}_{1}$, when compared with those of previous reports, this finding indicated that there is no similarity with the findings of other researchers [4]. Hoseini et al. (2012) reported differences in birth weights of black Lori goats and their crosses with Saanen. The results depicted in Table 1 related to weaning weight indicated that weaning weight of kids increased $(\mathrm{P}<0.05)$ the $\mathrm{P}$-value indicates the difference is significant. These finding were in line with other results $[1,5,6]$. The average of daily milk records were $0.65 \pm 0.05 \mathrm{~kg}$ and $1.31 \pm 0.12 \mathrm{~kg}$ for native and crossed $\mathrm{F}_{1}$ respectively. These significant results were similar to the latest research about native black Lori goat $\times$ Saanen in Qom province. When the results of this study are compared with the results of previous research, it is found that they are very close to related findings, which reported significant differences between native with crossed goats, and confirmed the positive effects of crossbreeding on milk yield traits directly $[4,5,7]$. In this study the milk yield increased significantly, however milk composition in term of milk fat and protein decreased through crossbreeding (Table 2). Although reduction in milk composition of crossbred offspring is a normal phenomenon due to negative correlation between quantitative and qualitative traits through animal breeding [2,7]. In this study, the reduced milk quality maybe due to higher quantity of the milk produced by crossbred goats. Guzler et al. (2010) also reported significant reduction in milk composition in Turkish native goat (Kilis) when crossed with Saanen [10].

\begin{tabular}{|c|c|c|}
\hline Body weight (kg) & Mamasani Goat & Crossed $\mathrm{F}_{1}$ \\
\hline Birth Weight & $2.85 \pm 0.23$ & $2.98 \pm 0.19$ \\
\hline Weaning Weight & $9.52 \pm 0.28^{b}$ & $11.61 \pm 0.28^{\mathrm{a}}$ \\
\hline
\end{tabular}

abSuperscript letters within the same row are significantly different $(\mathrm{P}<0.05)$

Table 1: Average of body weight of Mamasani goat and their crosses with Saanen

\begin{tabular}{|c|c|c|}
\hline & Mamasani Goat & Crossed $_{1}$ \\
\hline Milk yield & $0.65 \pm 0.05^{\mathrm{a}}$ & $1.31 \pm 0.12^{\mathrm{b}}$ \\
\hline Fat\% & $4.85 \pm 0.13^{\mathrm{a}}$ & $3.91 \pm 0.11^{\mathrm{b}}$ \\
\hline Protein\% & $4.12 \pm 0.03^{\mathrm{a}}$ & $3.6 \pm 0.15^{\mathrm{b}}$ \\
\hline
\end{tabular}

ab Superscript letters within the same row are significantly different $(\mathrm{P}<0.05)$

Table 2: Average of milk yield (L/day) and Composition of Mamasani goat and their crosses with Saanen

Other reports indicated that crossbreeding of native goats with genetically modified goats resulted in improved performance traits such as milk and gain traits [5,10,11]. Moameni et al. (2012) reported that crossbreeding between Sahelian goats with AngloNubian goats improved their growth rate and milk production.

\section{Conclusion}

According to the results of present study we can demonstrate that weight gain and milk production traits of crossed goats were improved after crossbreeding of native Mamasani goat $\times$ Saanen. Also milk yield in crossed $\mathrm{F}_{1}$ goats increased significantly compare to Mamasani goats, however milk composition (fat and protein percentage) decreased significantly. These findings indicated that crossbreeding of native goats with Saanen had positive effects on performance traits such as weight gain and milk yield.

\section{References}

1. Heidari M, Khashui A (2008) Comparison of growth traits and milk composition on seven goat genetic groups in Yazd province. Proceeding of 3th Animal Science Congress, Ferdowsi University of Mashad, Iran.

2. Assan N (2013) Crossbreeding as a strategy to increase productivity in resource poor goat keepers in the rural areas of Zimbabwe. Int J Sci Knowled Vol 2: 52-6. 3. Hoseini SM (2012) Comparison the genetic potential of some growth and milk traits of crossed Saanen with native goats versus native goats in Qom province, M.Sc Thesis Azad University of Saveh, Iran.

4. Donkin EF (1997) Productivity and Disease of saanen, Indigenous and Crossbred goats on zero Grazing, Medical University of Southern Africa.

5. Dinh VB, Do TV, Pham TB (1998) Study to find out the performance of F1 between Indian and local Co in Vietnam raising condition, Proceeding of Workshop of Animal Production Science.

6. Karua SK, Banda JW (1989) The performance of the small East African goats and their saanen crosses in Malawi. M.Sc Thesis, University of Malawi, Malawi.

7. Serradilla JM (2001) Use of high yielding goat breeds for milk production. Livestock Product Sci 71: 59-73.

8. Koch RM, Dikerson GE, Cundif LV, Gregory KE (1985) Retained heterosis in advanced generations among Angus and Herford crossbred cattle. J Anim Sci 60: 1117-32.

9. Momani, MS, Sanogo S, Coulibaly D, Al-Olofi S, Alkhewani T (2012) Growth performance and milk yields in Sahelian $\times$ Anglo-Nubian goats following crossbreeding in the semi-arid zone of Mali. Agricultural Tropica et subtropica 45: 117-25. 
10. Guzler N, Say D, Kacar A (2010) Compositional changes of Saanen $\times$ Kilis goats, milk during lactation. GIDA 35: 325-30.

11. Gebrelul S, Sartin LS, Iheanacho M (1994) Genetic and non-genetic effects on the growth and mortality of Alpine, Nubian and crossbred kids. Small Ruminant Res 13: 169-76.

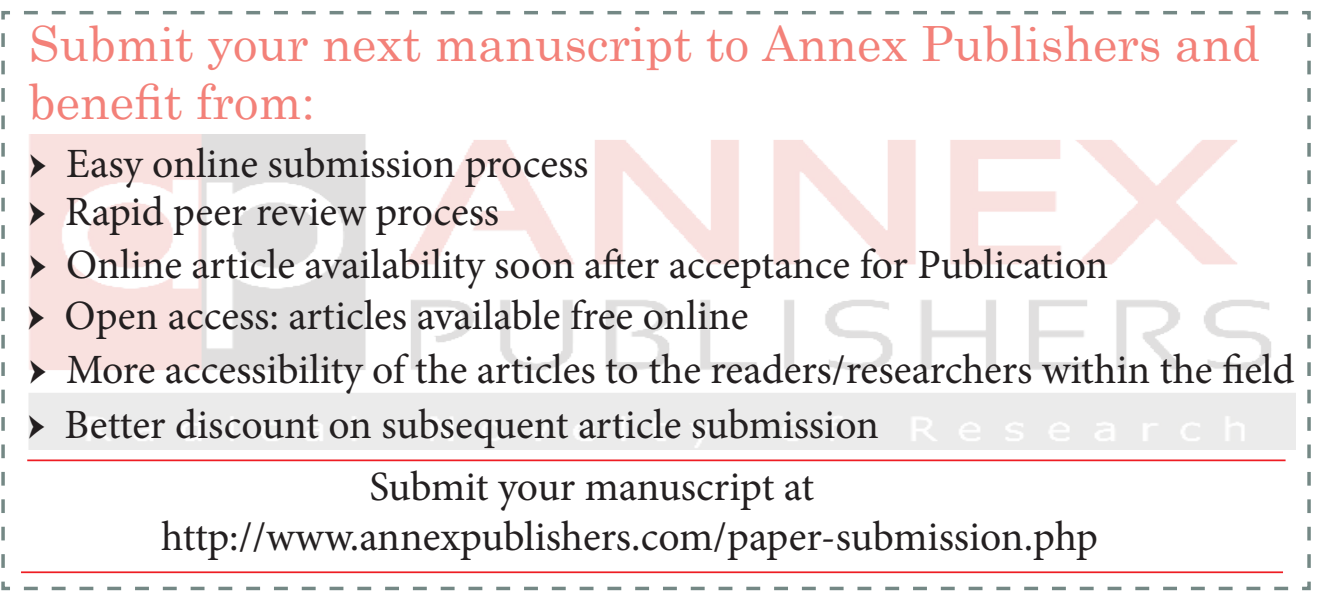

